\title{
Miljø og helse
}

\author{
Per Nafstad ${ }^{1,2}$ og Erik Dybing ${ }^{2}$ \\ 1) Seksjon for epidemiologi og forebyggende medisin, Institutt for allmenn- og samfunnsmedisin, \\ Det medisinske fakultet, Universitetet i Oslo \\ 2) Divisjon for epidemiologi og Divisjon for miljømedisin, Nasjonalt folkehelseinstitutt, Oslo \\ Korrespondanse: Per Nafstad, Seksjon for epidemiologi og forebyggende medisin, Institutt for allmenn- og samfunnsmedisin, \\ Det medisinske fakultet, Universitetet i Oslo, Postboks 1030 Blindern, 0318 Oslo \\ Telefon 22850550 E-post: per.nafstad@medisin.uio.no
}

Til alle tider har det vært stilt spørsmål om hvordan miljøet påvirker vår helse. Allerede i det 5. århundre f. Kr. påpekte Hippokrates nødvendigheten av å forstå miljøet og dets betydning for sykdom og sykdomsutvikling (1), og i vår tid dukker det stadig opp mer eller mindre velbegrunnede oppslag om helseskadelige miljøpåvirkninger. Et svært illustrerende og godt begrunnet slikt eksempel er hetebølgen i Frankrike i 2003 hvor det ble anslått at mer enn 11000 personer døde som følge av heten (2). Å stille spørsmål om hvorvidt miljøeksponering kan gi helseskade synes rimelig. Antagelig finnes det helseskadelig miljøeksponering som vi i dag ikke er klar over. Videre kan våre forstillinger om sammenhengene mellom miljø og helse være unøyaktige pga. ufullstendig eller manglede vitenskaplig dokumentasjon. Vår kunnskap om sammenhenger mellom miljø og helse kan økes gjennom eksperimentelle og epidemiologiske undersøkelser og begge metodene har vært og er i utstrakt bruk. I tillegg har erfaringer fra arbeidsmiljøforskning vært brukt til å anslå helseeffekter av for eksempel radoneksponering (3).

Temaet for dette nummeret av Norsk Epidemiologi er miljøepidemiologi. Miljø er et vidt begrep. For eksempel inkluderes både biologiske, kjemiske, fysiske og sosiale faktorer i kommunehelselovens paragraf om miljørettet helsevern (4), og miljømedisin har vært beskrevet som et fagområde som dekker de kjemiske, fysiske og biologiske miljøfaktorer (5). Hovedutfordringen i miljøepidemiologien er å utvikle eksponeringsmål og forskningsmetoder som egner seg for å studere sammenhenger mellom miljø og helse i befolkningsundersøkelser.

I Norge i motsetning til de fleste andre land, er begrepet miljøepidemiologi ("environmental epidemiology") vært lite brukt og miljøepidemiologi er ingen egen disiplin. Epidemiologisk forskning har i Norge i hovedsak vært bygd rundt miljøer som studerer spesielle sykdommer eller befolkningsgrupper. Norges forskningsråd initierte en satsning på miljøepidemiologi i Norge i 1992 ved å opprette et eget program for miljøepidemiologi. Dette førte til aktiviteter, men ikke til at miljøepidemiologi har blitt noe sentralt begrep eller til organisatoriske konsekvenser for epidemiologisk forskning. Det finnes for eksempel ikke noe miljøepidemiologisk institutt, seksjon eller avdeling.
Dette betyr selvfølgelig ikke at det ikke foregår forskning og fagutvikling som faller inn under begrepet miljøepidemiologi, noe dette nummeret av Norsk Epidemiologi viser, men en effekt av manglende fokusering kan ha vært at Norge har kommet etter i den internasjonale kunnskaps- og metodeutviklingen innen miljøepidemiologi.

En ekspert på miljøepidemiologi og spesielt på luftforurensningepidemiologi, professor Bert Brunekreef ved Universitetet i Utrecht, har blitt bedt om å kommentere norsk miljøepidemiologisk forskning fra utsiden (6). Brunekreef er for tiden deltidsansatt ved Nasjonalt folkehelseinstitutt for å bidra til utvikling av miljøepidemiologien $\mathrm{i}$ vårt land. Hans vurderinger gir grunn til en smule norsk selvtillit, selv om antall publikasjoner per innbygger med miljø i tittel etc. neppe er et optimalt mål for kvalitet og produktivitet, spesielt for et land med et lavt befolkningstall. Brunekreef peker på at geokoding kan være en egnet vei for å utvikle miljøepidemiologien videre.

\section{EKSPONERING OG DESIGN}

En sentral utfordring for miljøepidemiologisk forskning er utviklingen av metoder for eksponeringsmålinger som egner seg for befolkningsundersøkelser. I tillegg er utfordringen å kunne finne forskningsdesign som kan utnytte tilgjengelige eksponeringsmål på en optimal måte. Dette krever utvikling av kompetanse og erfaring som kan være av generell betydning for epidemiologisk forskning. Det er mulig at den norske organiseringen av epidemiologisk forskning ikke er optimal for å fremme en slik utvikling. Et eksempel kan ha vært bruken av tidsrekkeundersøkelser i epidemiologisk forskning. Disse undersøkelser har vært en vesentlig årsak til den senere tids utvikling av kunnskap om helseeffekter av luftforurensning (7), en utvikling Norge knapt har deltatt i (8).

\section{GEN-MILJØ SAMSPILL}

Gen-miljøinteraksjon har vært og er et moteord. Eksplosjonen i kunnskapen om gener og i teknikker for å studere våre gener og deres funksjoner har skapt store forventninger til at vi kan avdekke samspillet mellom 
arv og miljø på en bedre måte. Så langt har denne forventningen i liten grad blitt innfridd. Fra et miljøståsted er det et klart inntrykk at mange forskere har et for enkelt syn på hva upresise og grove eksponeringsmålinger kan gi og ser for lett på nødvendigheten av tilstrekkelig eksponeringsvariasjon i den aktuelle studiepopulasjonen. Undersøkelser som skal studere samspillet mellom arv og miljø, kommer neppe noen gang bort fra behovet for gode eksponeringsmål og optimale valg av forskningsdesign. Kontraster i eksponering innen studiepopulasjonen er av avgjørende betydning for å kunne påvise helseeffekter av eksponering. Manglende eller små kontraster i eksponering vil antagelig være en vesentlig begrensning for å kunne påvise helseeffekter av miljøpåvirkning. For eksempel vil dette antagelig være et vesentlig problem hvis en vil bruke tvillingundersøkelser til å undersøke miljøfaktorers betydning for helse og sykdom. Her vil en forvente at det oftest vil være små variasjoner i eksponering for både eneggede og toeggede tvillinger.

\section{REGIONALE FORSKJELLER}

Et trekk i dagens samfunn er at mange av de miljøeksponeringene en bekymrer seg for $\mathrm{i}$ vestlige land forekommer i langt høyere nivåer og derfor har potensielt langt større helseeffekter i utviklingsland. I dette nummeret beskrives et unikt intervensjonsprosjekt fra Guatemala som har potensialet i seg for å påvise helseeffekter av innendørs luftforurensning (9). Dette forskningsfeltet har slitt med mangel på gode eksponeringsmål og egnede design for å studere slike sammenhenger. Studien hvor norske forskere utgjør en betydelig del av staben, har et utmerket og velegnet forskningsdesign for å studere inneklima-effekter. Studien har også lagt opp til gode og relevante ekspone- ringsmålinger og helseutfall. Selv om eksponeringsnivåene $\mathrm{i}$ denne studien kan forventes å være forskjellige og langt "verre" enn den en kan erfare $\mathrm{i}$ Norge, er det å håpe at studien ikke bare kan gi kunnskap om miljøeksponering og helse i Guatemala, men at noen av resultatene også er nyttig for våre forhold. Dette eksemplet illustrerer også at miljøforhold kan variere betydelig mellom land og at forskningsresultater fra et område av verden må vurderes kritisk før en anser at tilsvarende sammenhenger har betydning for for eksempel norske forhold.

\section{SVAKE ASSOSIASJONER}

Det er vanlig at befolkningsundersøkelser påviser relativt svake assosiasjoner mellom miljøeksponering og helse. Den sterke sammenhengen som ble funnet mellom tobakksrøyk og kreft og andre helseutfall, er antagelig en spesiell situasjon. Behovet for konsistente funn fra flere undersøkelser med gode forskningsdesign og at det er en rimelig biologisk forklaring på sammenhengen, blir derfor viktig og nødvendig for å øke tiltroen til at det er snakk om en reel sammenheng. Blaasaas og Tynes' oversiktsartikkel om elektromagnetiske felter og helse demonstrerer godt hvor komplisert og vanskelig det er å utvikle oppfatninger som er dekkende for den kunnskap en per i dag har om en svak sammenheng mellom miljø og helse påvist $\mathrm{i}$ en rekke undersøkelser, men uten en dokumentert biologisk forklaring (10). En ting er å lage faglige korrekte formuleringer, det kan være enda vanskeligere å formidle slik kunnskap for publikum og forvaltning. Kunnskap om sammenhengen mellom miljø og helse er etterspurt. Formidlig av slik kunnskap vil derfor være en vedvarende utfordring og medieoverskrifter minner en om at dette ikke alltid går greit.

\section{REFERANSER}

1. Hippokrates. Über die Umwelt. Berlin Akademie, Tyskland 1999. ISBN 3-05-003344-4.

2. Ranhoff AH. Eldre personer er sårbare i ekstreme værsituasjoner. Norsk Epidemiologi 2004; 14 (2): 199-205.

3. Stigum H, Strand T, Magnus P. A cost-effect analysis of an intervention against radon in homes. Norsk Epidemiologi 2004; 14 (2): 193-198.

4. Kommunehelsetjenesteloven. Gyldendals forlag, Oslo 1995. ISBN 82-417-0569-7.

5. Dybing E. Miljømedisin - status og utfordringer. Tidsskr Nor Lageforen 1992; 112: 1259-1262.

6. Brunekreef B. Environmental epidemiology in Norway. Norsk Epidemiologi 2004; 14 (2): 134-136.

7. http://www.euro.who.int/document/E82792.pdf. 02.05.2004.

8. Refsnes M, Låg M, Hetland RB, Schwartze PE. Helseeffekter av byluftpartikler. Norsk Epidemiologi $2004 ; 14$ (2): $145-154$

9. Smith-Sivertsen T, Díaz E, Bruce N, Díaz A, Khalakdina A, Schei MA, McCracken J, Arana B, Klein R, Thompson L, Smith KR. Reducing indoor air pollution with a randomised intervention design - A presentation of the Stove Intervention Study in the Guatemalan Highlands. Norsk Epidemiologi 2004; 14 (2): 137-143.

10. Blaasaas KG, Tynes T. Nettfrekvente elektromagnetiske felt og helseeffekter. Norsk Epidemiologi 2004; 14 (2): $177-186$. 